\title{
Assessment of folate receptor alpha and beta expression in selection of lung and pancreatic cancer patients for receptor targeted therapies
}

\author{
Jiayin Shen ${ }^{1}$, Yingwen Hu${ }^{1,2}$, Karson S. Putt ${ }^{2}$, Sunil Singhal ${ }^{3}$, Haiyong Han ${ }^{4}$, Daniel \\ W. Visscher ${ }^{5}$, Linda M. Murphy ${ }^{6}$ and Philip S. Low ${ }^{1,2}$ \\ ${ }^{1}$ Department of Chemistry, Purdue University, West Lafayette, IN, USA \\ ${ }^{2}$ Institute for Drug Discovery, Purdue University, West Lafayette, IN, USA \\ ${ }^{3}$ Division of Thoracic Surgery, Department of Surgery, University of Pennsylvania School of Medicine, Philadelphia, PA USA \\ ${ }^{4}$ Clinical Translational Research Division, The Translational Genomics Research Institute, Phoenix, AZ, USA \\ ${ }^{5}$ Department of Laboratory Medicine and Pathology, Mayo Clinic College of Medicine, Rochester, MN, USA \\ ${ }^{6}$ Department of Biochemistry and Molecular Biology, Mayo Clinic College of Medicine, Rochester, MN, USA \\ Correspondence to: Philip S. Low, email: plow@purdue.edu
}

Keywords: folate receptor alpha; folate receptor beta; lung cancer; pancreatic cancer; tumor associated macrophages Abbreviations: folate receptor (FR); tumor microarray (TMA)

Received: September 13,2017 Accepted: November 19, $2017 \quad$ Published: December 15, 2017

Copyright: Shen et al. This is an open-access article distributed under the terms of the Creative Commons Attribution License 3.0 (CC BY 3.0), which permits unrestricted use, distribution, and reproduction in any medium, provided the original author and source are credited.

\section{ABSTRACT}

A number of folate receptor (FR) targeted small molecular drugs and monoclonal antibodies have been introduced into clinical trials to treat FR positive cancers. Because the therapeutic efficacy of these drugs depends prominently on the level of FR-a expression on the cancer cells, patients have been commonly selected for FRtargeted therapies based on the intensity of a folate-targeted radioimaging agent. Unfortunately, uptake of such imaging agents can be mediated by both major isoforms of the folate receptor, FR-a and FR- $\beta$. Logically, if the FR positive cell population in a tumor mass is dominated by FR- $\beta$ positive macrophages, patients could be selected for therapy that have few FR-expressing cancer cells. Although several IHC studies have examined expression of either FR-a or FR- $\beta$, no study to date has investigated expression of both FR- $a$ and FR- $\beta$ in the same tumor mass. Herein, we utilize monoclonal antibodies specific for FR-a (mAb343) and FR- $\beta$ ( $m 909)$ to query each isoform's expression in a range of cancers. We show that lung and pancreatic adenocarcinomas express the full spectrum of FR-a and FR- $\beta$ combinations with $\sim 76 \%$ of lung adenocarcinomas expressing both FR-a and FR- $\beta$ while pancreatic cancers express primarily FR- $\beta$. Thus, while folate-targeted imaging of lung cancer patients might accurately reflect the expression of FR-a on lung cancer cells, imaging of pancreatic cancer patients could mislead a physician into treating a nonresponding patient. Overall, these data suggest that an independent analysis of both FR- $a$ and $F R-\beta$ should be obtained to predict the potential efficacy of a folate-targeted drug.

\section{INTRODUCTION}

Folate receptors (FR) are one family of membraneanchored receptors that participate in the transport of folate into cells [1]. Four isoforms of FR $(\alpha, \beta, \gamma$ and $\delta)$ have been identified, with each displaying a unique expression pattern in normal tissues. FR- $\alpha$ is primarily found on the apical surfaces of epithelial cells in the mammary ducts, lungs, kidneys and the choroid plexus [2-4], whereas FR- $\beta$ has only been found on activated but not resting or quiescent myeloid cells $[5,6]$. FR- $\gamma$ is a predominately secreted receptor that is found in very 
low concentrations in the blood $[7,8]$, while FR- $\delta$ is only known to be expressed on ova and regulatory T-cells [9].

Unlike this restricted FR expression in normal tissues, a broad range of cancers express one or more FRs. FR- $\alpha$ has been found on cancers of the ovary, breast, head \& neck, endometrium, lung, bladder, pancreas, colon and kidney [10-21], with an estimated $40 \%$ of human cancers overexpressing the receptor. More recently, FR- $\beta$ has been shown to be expressed on both malignant cells and tumor-associated macrophages from a wide variety of cancers, including cancers of the lung, breast, liver, brain, uterus, thyroid, stomach, ovary, head \& neck, skin, kidney, pancreas, bladder, cervix, esophagus, prostate, testis, and colon $[6,22]$. In fact, over $25 \%$ of the tumor sections examined exhibited FR- $\beta$ expression on the cancer cells and over $50 \%$ had expression on their tumor-associated macrophages [22].

Due to upregulation of FRs in many tumors, multiple diagnostic and therapeutic agents have been targeted to an FR for imaging or treating the FR positive cancer [23-30]. In fact, six folate-targeted drugs [26-30], four folate-targeted imaging agents [31, 32] and an FR- $\alpha$ specific monoclonal antibody $[30,33]$ have been introduced into human clinical trials over the last several years. In many of these trials, patients have been selected for an FR-targeted therapy based on the intensity of their tumor's uptake of a folate-targeted radioimaging agent. Unfortunately, these images do not distinguish whether imaging agent retention is mediated by FR- $\alpha$ or FR- $\beta$, and hence a patient could be selected for folate-targeted chemotherapy when most of the imaging agent uptake was by FR- $\beta$ positive macrophages. Because FR- $\beta$ positive macrophages do not respond to most antimitotic drugs and since elimination of such macrophages would also not directly eradicate the cancer cells, it is conceivable that some patients will have been inaccurately selected for an FR-targeted chemotherapy because their tumors were replete with macrophages.

Unfortunately, there is currently no published information on the independent expression of FR- $\alpha$ and FR- $\beta$ in the same tumor sample. In fact, the only published data relevant to this topic reports the binding of an antibody with reactivity towards both FR- $\alpha$ and FR- $\beta$ in ovary and lung carcinomas [34] and the FR- $\alpha$ and FR- $\beta$ mRNA levels in ovarian and fallopian adenocarcinomas [11], which often correlate poorly with protein expression $[35,36]$, leaving considerable uncertainty over the relative FR protein levels in these cancers. In an attempt to obtain an initial indication regarding the levels of FR- $\alpha$ and FR- $\beta$ proteins in the same tumor samples, we employed two monoclonal antibodies with non-overlapping specificities for FR- $\alpha$ and FR- $\beta$. Quantitative analyses of IHC stains of a large number of lung and pancreatic cancer specimens reveal that both FR- $\alpha$ and FR- $\beta$ are commonly upregulated in both malignancies and that in many cases, the level of FR- $\beta$ expression exceed that of FR- $\alpha$. These data argue for the need to develop separate imaging agents for both FR- $\alpha$ and FR- $\beta$.

\section{RESULTS}

\section{Antibodies}

The monoclonal antibodies for use in staining tissue sections for FR- $\alpha$ (mAb343) and FR- $\beta$ (m909) were selected based on their abilities to specifically stain their respective FR isoforms in a previous publication $[22,37]$. However, in order to confirm their FR isoform specificities, cell lines that express only FR- $\alpha$ (MDAMB-231) or only FR- $\beta$ (transfected CHO- $\beta$ ) were used to query binding via both flow cytometry and western blotting. As shown in Figure 1, mAb343 only bound to MDA-MB-231 cells, while m909 only bound to CHO- $\beta$ cells. These results agree with prior studies and confirm that binding of mAb343 and m909 is specific for FR- $\alpha$ and FR- $\beta$, respectively.

\section{Multi-cancer TMA}

In order to investigate the expression of FR- $\alpha$ and FR- $\beta$ in the same tumor specimens, sequential tissue sections were stained with mAb343 and m909 as outlined in the Methods. The staining intensity of each monoclonal antibody was then assessed by a trained pathologist and scored on a scale of 0 to 3 , where 0 indicated no visible staining and 3 designated the highest level of staining.

Initially, IHC staining was performed on a broad multi-cancer tumor microarray (TMA) containing $\sim 8-10$ sections per cancer type and 8 total cancer types. FR- $\alpha$ and/or FR- $\beta$ staining was observed in most specimens (see representative stains in Figure 2), suggesting that FR-targeted imaging agents should reveal the locations and sizes of most of these human cancers. Unfortunately, variability in FR- $\alpha$ and FR- $\beta$ staining was so large in these samples that statistically significant conclusions could not be drawn from the limited number of samples available. Therefore, much larger arrays of lung (212 different tumors) and pancreatic (64 different tumors) cancer TMAs that contained adjacent tissue sections were obtained and used for statistical evaluation of FR- $\alpha$ and FR- $\beta$ expression.

\section{Lung adenocarcinoma TMA}

As shown in Figure 3, expression of FR- $\alpha$ and FR- $\beta$ in lung adenocarcinoma sections varied significantly, resulting in all possible ratios of FR- $\alpha$ to FR- $\beta$ expression (i.e., FR- $\alpha$ low/FR- $\beta$ low, FR- $\alpha$ low/FR- $\beta$ high, FR- $\alpha$ high/FR- $\beta$ low, FR- $\alpha$ high/FR- $\beta$ high). When analyzed individually, $76 \%$ of the 212 total tumor sections (i.e. 162 samples) stained positive for FR- $\alpha$ and $76 \%$ also stained positive for FR- $\beta$. Importantly, this percentage of 
FR- $\alpha$ and FR- $\beta$ positive tumors is similar to that reported in previous studies that simply examined each receptor individually $[16,22,37]$. When both FR- $\alpha$ and FR- $\beta$ were subsequently analyzed on the same tumor specimen, however, the vast majority (97\%) of tumors that expressed one FR isoform also expressed the other. Similarly, nearly every tumor that expressed few or no FR- $\alpha$ also expressed few or no FR- $\beta$. Closer inspection of the FR positive tumors further revealed that FR- $\alpha$ and FR- $\beta$ rarely colocalized to the same region of the malignant lesion, with FR- $\alpha$ usually distributed throughout the cancer mass and FR- $\beta$ commonly clustered in regions of high immune cell infiltration. Not surprisingly, the majority of FR- $\alpha$ appeared to reside on cancer cells while most of FR- $\beta$ was localized to macrophage-like cells.

\section{Staining of pancreatic TMAs}

In order to explore the expression patterns of the FR isoforms in an unrelated tumor type, pancreatic cancer sections were similarly stained and analyzed. As shown in Figure 4, 95\% of all tissue sections stained positive for either FR- $\alpha$ or FR- $\beta$. However, in contrast to the staining pattern seen in lung cancer, roughly half of the tumor
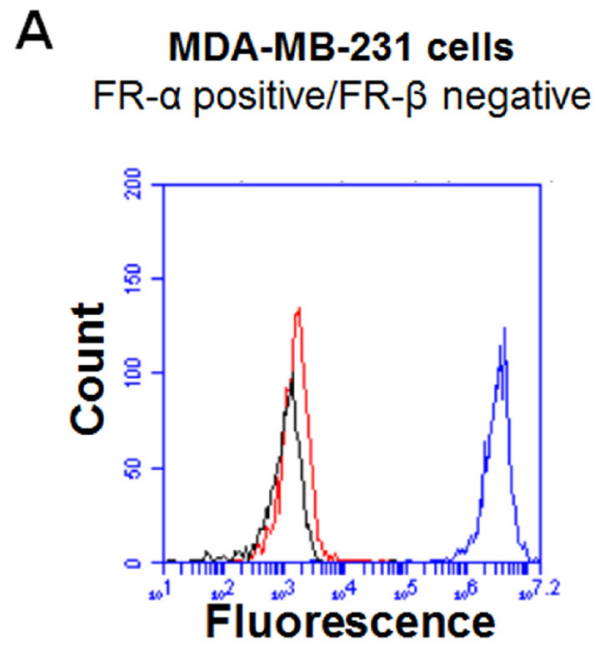

B

\section{CHO- $\beta$ cells FR- $\alpha$ negative/FR- $\beta$ positive}
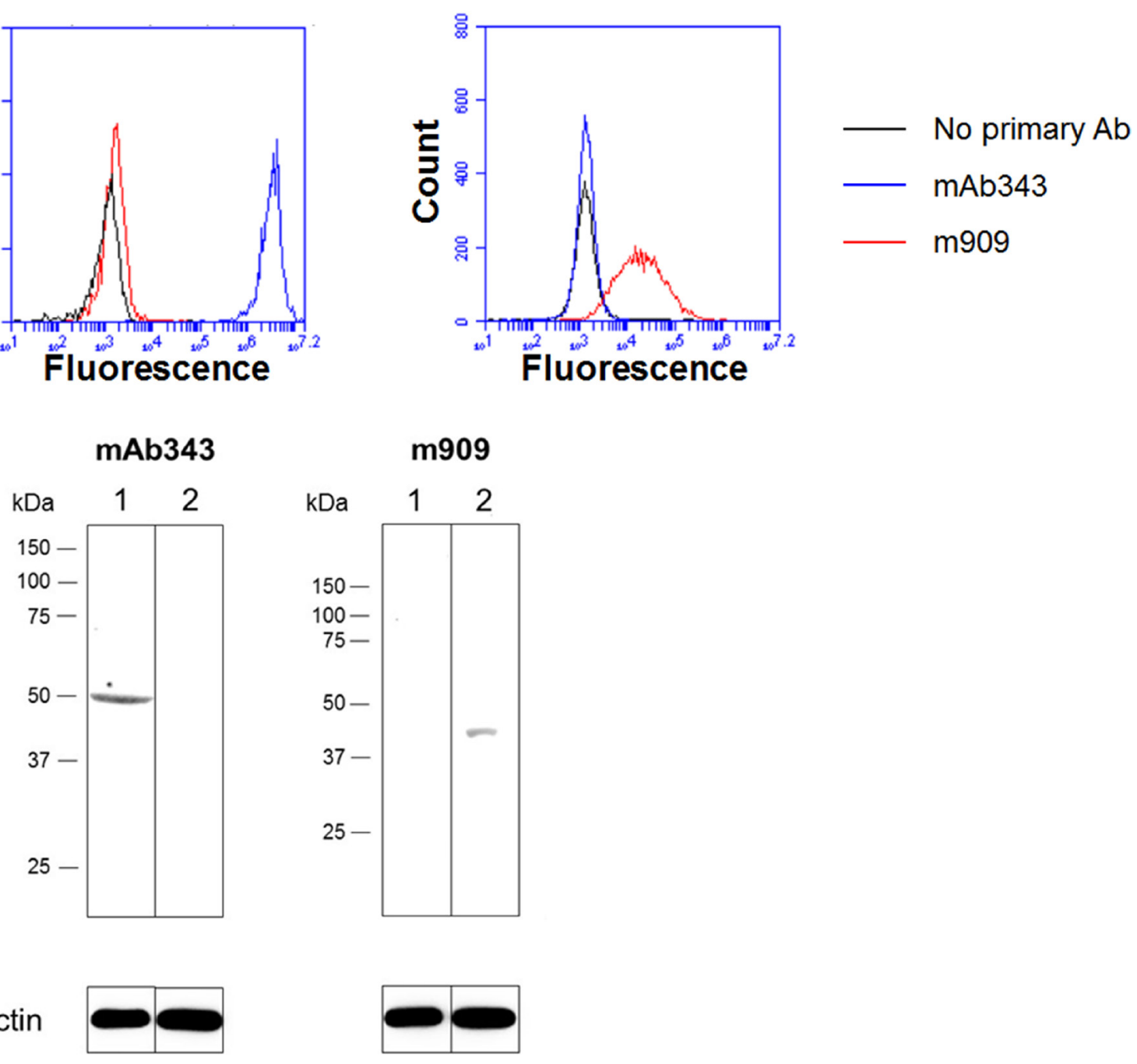

Figure 1: FR isoform specificity of antibody staining. (A) MDA-MB-231 (FR- $\alpha$ positive/FR- $\beta$ negative) and transfected CHO$\beta$ cells (FR- $\alpha$ negative/FR- $\beta$ positive) were incubated with mAb343 (blue line), m909 (red line) or no primary antibody (black line) for 30 minutes at room temperature. Cells were washed and incubated with secondary antibody for 30 min at room temperature. Cells were washed again and analyzed by flow cytometry. (B) Lysate from FR- $\alpha$ positive/FR- $\beta$ negative cell line MDA-MB-231 (lane 1) and the FR- $\alpha$ negative/FR- $\beta$ positive transfected cell line CHO- $\beta$ (lane 2 ) were ran on a gel, transferred to nitrocellulose, blocked overnight at $4{ }^{\circ} \mathrm{C}$, washed, and blotted with mAb343 or m909 overnight at $4^{\circ} \mathrm{C}$. After washing again, blots were incubated with HRP-conjugated secondary antibody for 1 hour at room temperature. A luminescent HRP substrate was added and blots were visualized. 
sections stained positive for only one FR isoform (i.e. with most of this subset staining positive solely for FR- $\beta$ ). Although very few pancreatic cancers stained positive for only FR- $\alpha$, roughly $45 \%$ expressed substantial numbers of both FR- $\alpha$ and FR- $\beta$.

To more precisely characterize the specific cells that carry the FR- $\alpha$ and FR- $\beta$ antigens, each $\mathrm{FR}^{+}$and $\mathrm{FR}^{-}$staining cell was carefully scrutinized for its specific cell type and location, and then categorized as either a cancer cell, macrophage-like cell located within the tumor margin, macrophage-like cell located outside the tumor margin, or other normal cell (endothelial cell, fibroblast, etc.). When only normal cells outside the tumor margins were analyzed, FR- $\alpha$ was present on $>80 \%$ of the samples examined where it was found almost exclusively on ductal epithelial cells. Very weak FR- $\beta$ staining was also observed outside of the tumor boundaries in $>60 \%$ of sections, with most of this staining found on either glandular cells or ductal epithelial cells. Curiously, macrophages found in these normal tissue regions were completely devoid of both FR- $\alpha$ and FR- $\beta$ staining
(Figure 5), suggesting they were neither activated to a proor anti-inflammatory phenotype.

More focused analyses of cancer cells in each of the tumor sections demonstrated that $\sim 50 \%$ of sections showed no FR- $\alpha$ or FR- $\beta$ staining. Moreover, the intensities of those cancer cells that did stain positive for either FR- $\alpha$ or FR- $\beta$ was relatively low, with an average staining intensity of 1.7 and 1.0, respectively (Figure 5). Additionally, staining of cancer cells was heterogeneous even among the same tissue section with an average relative standard deviation of $23 \%$ and a range between $\sim 12 \%$ and $45 \%$ when grayscale values of cells were quantified. When tumor associated macrophages were specifically examined, $26 \%$ were found to express FR- $\alpha$ while $86 \%$ were positive for FR- $\beta$. Not surprisingly, the staining intensity of FR- $\beta$ was much greater in the tumor associated macrophages than in any other cells examined (an average intensity of $\sim 2.5$; Figure 5).

One of the more surprising observations was that staining of neither FR- $\alpha$ nor FR- $\beta$ was limited to the cell type in which it is normally expressed. That is, although

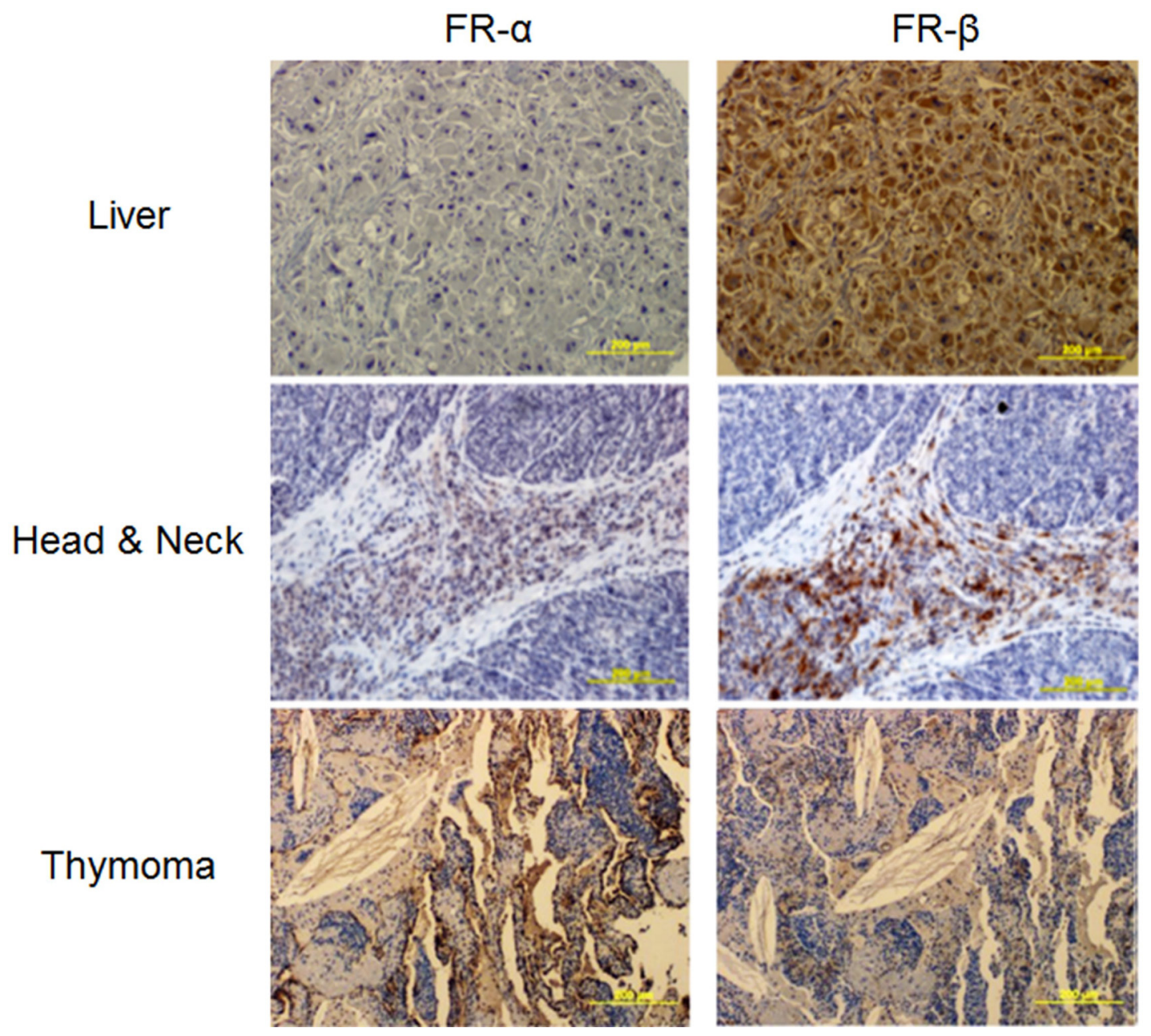

Figure 2: Representative images of various neoplastic tissues sequentially stained with the FR- $\alpha$ and FR- $\beta$ specific monoclonal antibodies $\mathrm{mAb343}$ and $\mathrm{m} 909$, respectively. 

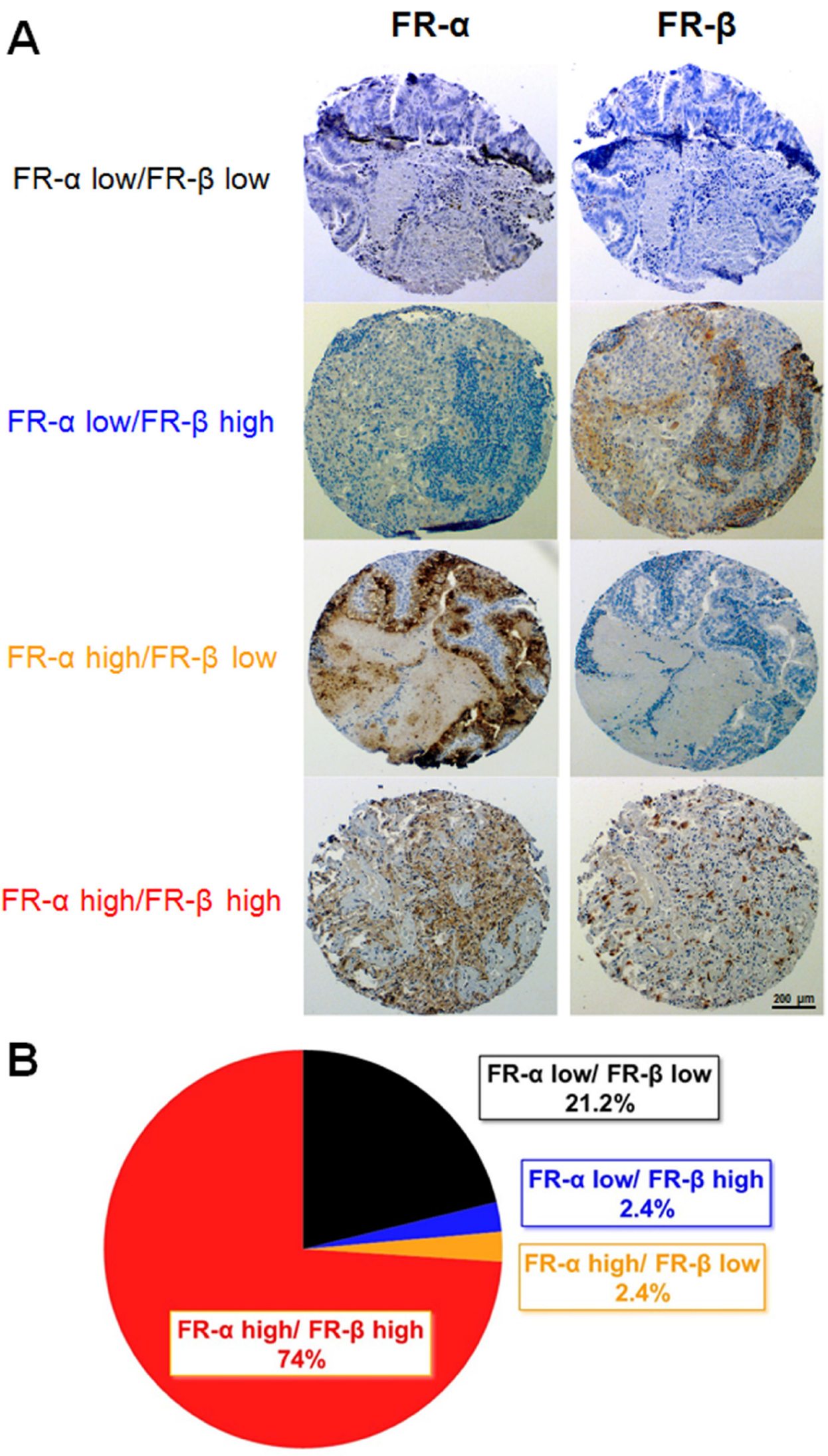

Figure 3: FR- $\alpha$ and FR- $\beta$ expression in lung cancer (adenocarcinomas) tissue sections. Sequential sections were stained with mAb343 or m909. (A) Representative images of each level of FR- $\alpha$ and FR- $\beta$ staining is shown. (B) Summary of the percentage of tissue sections staining positive for FR- $\alpha$ and FR- $\beta(n=212)$. 
FR- $\alpha$ is normally observed on cancer cells [10-21] and a minor subset of healthy epithelial cells [2-4], FR- $\alpha$ was also observed on a subpopulation of tumor-associated macrophages. Similarly, while FR- $\beta$ expression was normally thought to be restricted to the activated subset of myeloid cells (i.e. pro- and anti-inflammatory monocytes and macrophages), it was also found on some cancer cells. While aberrant gene expression might be invoked to account for these unanticipated expression patterns, it should also be noted that folate receptors are glycosylphosphatidylinositol- anchored proteins and that GPI-anchored proteins can jump from one membrane to another [38]. Moreover, cancer cells are similarly known to release large quantities of exosomes and/or microparticles that contain cancer cell proteins [39], and these exosomes/microparticles can fuse with adjacent normal cells and thereby transfer their proteins to the normal cell plasma membranes. Obviously, further investigation of this unexpected finding will be required before an unequivocal mechanism of intercellular FR transfer can be determined. However, the data do suggest

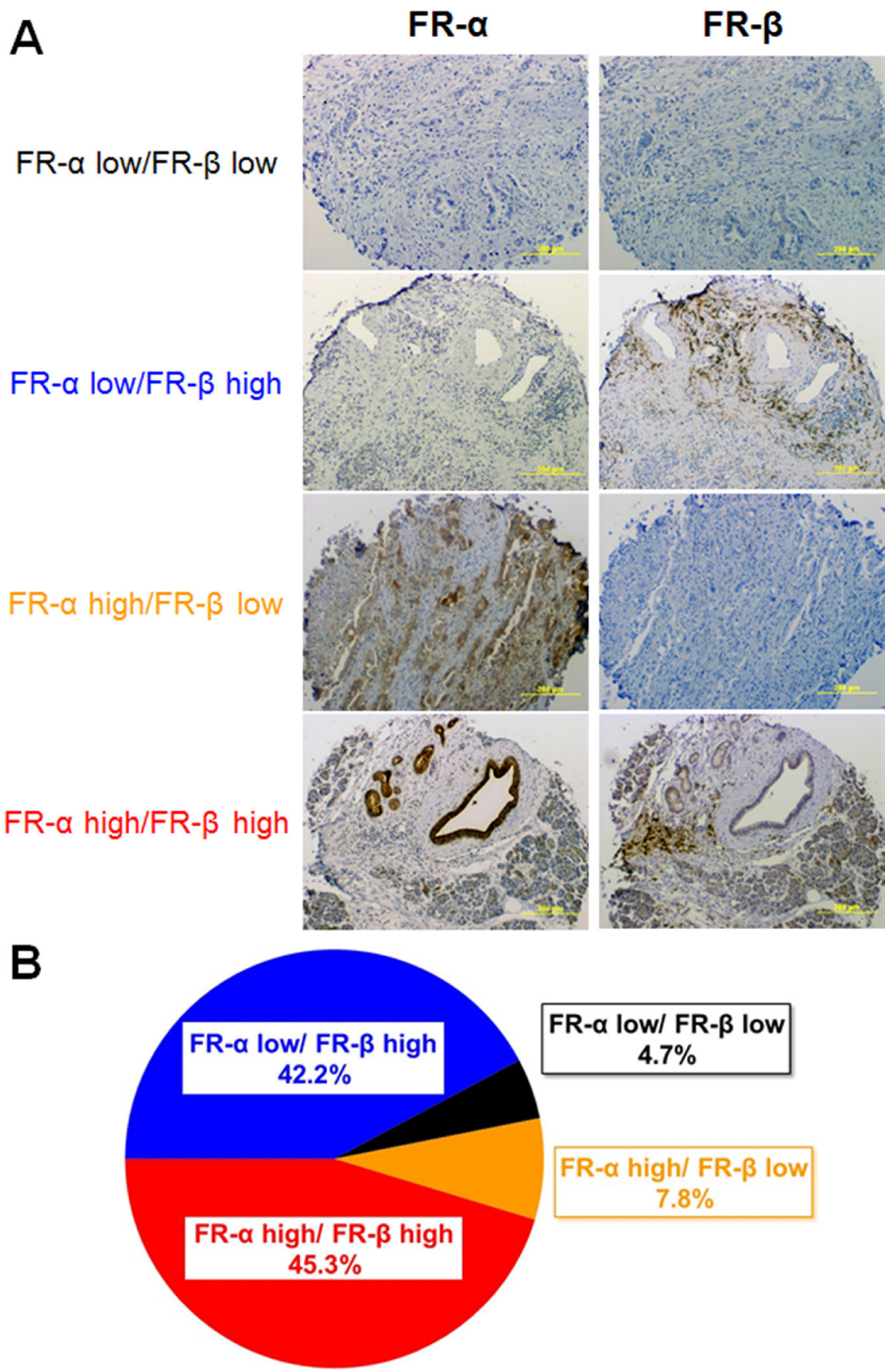

Figure 4: FR- $\alpha$ and FR- $\boldsymbol{\beta}$ expression in pancreatic cancer tissue sections. Sequential sections were stained with $\mathrm{mAb} 343$ or m909. (A) Representative images of each level of FR- $\alpha$ and FR- $\beta$ staining is shown. (B) Summary of the percentage of tissue sections staining positive for FR- $\alpha$ and FR- $\beta(n=64)$. 
that some sharing of membrane components likely occurs among cells within a tumor mass and that this sharing can alter the antigen staining pattern with the tumor.

\section{DISCUSSION}

To the best of our knowledge, this is the first delineation of the independent expression of FR- $\alpha$ and FR- $\beta$ in the same tumor mass. Our analysis shows that all four combinations of high and low FR- $\alpha$ and FR- $\beta$ expression can be found in any single cancer type and that expression can be heterogeneous, even within the same tumor sample. Taken together, this suggests that the intensity of an FR-targeted imaging agent cannot be accurately exploited to indicate the level of FR- $\alpha$ expression on a tumor's cancer cells. This conclusion is especially important when the imaging agent is used to select patients for treatment with a folate receptor-targeted therapy, since delivery of a folate-linked therapeutic agent to a tumor whose imaging agent uptake is dominated by FR- $\beta$ expressing macrophages may have little therapeutic impact on the patient's tumor. Additionally, the heterogeneity within the tumor could result in a strong selective pressure for the survival and proliferation of non or low FR-expressing malignant cells, possibly resulting in recurrence of disease.

In contrast to the above scenario, when a folatelinked imaging agent is exploited for tumor localization, staging, intra-operative imaging, or analysis of cancer recurrence, the added signal intensity arising from imaging agent uptake by both tumor cells and tumor-associated macrophages can augment the sensitivity of the procedure.

\section{Cancer Cells}

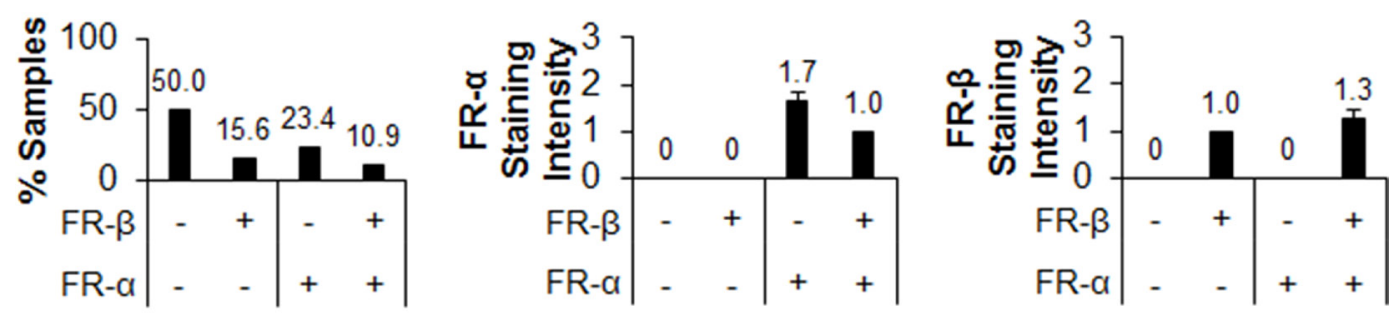

\section{Macrophages in Adjacent Normal Tissue}
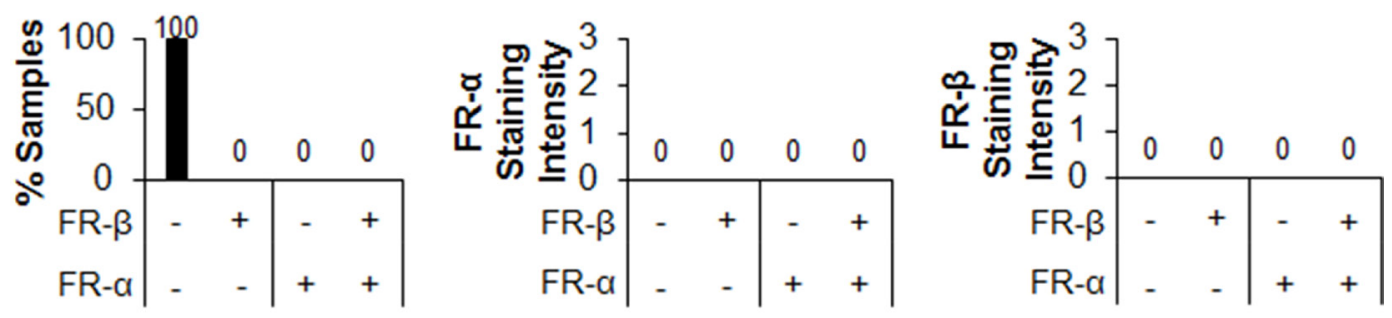

\section{Tumor Associated Macrophages}
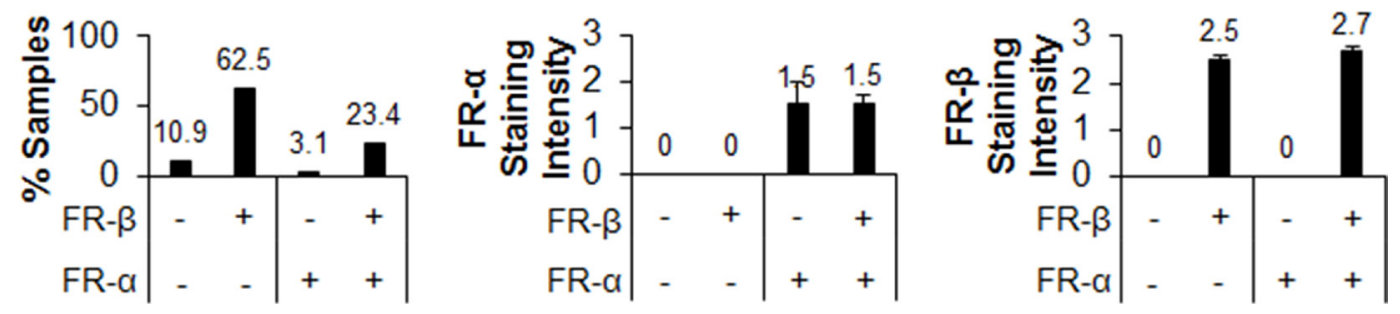

Figure 5: FR- $\alpha$ and FR- $\beta$ expression in different cell populations within pancreatic cancer tissue samples. Sequential sections were stained with mAb343 and m909. Staining of macrophages, normal cells, and cancer cells were graded on the same 0 to 3 scale $(n=64)$. The first column is a summary of the percentage of tissue sections that stained positive in each FR staining group (FR- $\alpha$ low/ FR- $\beta$ low, FR- $\alpha$ low/FR- $\beta$ high, FR- $\alpha$ high/FR- $\beta$ low, and FR- $\alpha$ high/FR- $\beta$ high). The second and third columns show the average staining intensity of FR- $\alpha$ and FR- $\beta$, respectively, in each of the four staining groups (error bars represent SEM). 
For example, $>65 \%$ of pancreatic tumors exhibited no FR- $\alpha$ cancer cell staining, but $>85 \%$ of samples had FR- $\beta$ positive tumor associated macrophages and $\sim 25 \%$ had FR- $\beta$ positive cancer cells. An imaging agent that would solely image FR- $\alpha$ might be totally inadequate for pancreatic cancer detection, but an FR isoform agnostic imaging agent might have the sensitivity to detect most if not all malignant lesions. Similarly, although most nonsmall cell lung cancers strongly express FR- $\alpha$, a subset expresses no FR- $\alpha$, but does express FR- $\beta$. In the case of fluorescence guided surgeries in which localization and resection of malignant lesions has been guided by an FR-targeted fluorescent dye, a number of tumor nodules have indeed been discovered that have expressed FR- $\beta$ but not FR- $\alpha$ [40]. Because failure to remove these hidden malignant lesions can lead to disease progression and death, the ability to exploit the added sensitivity contributed by FR- $\beta$ imaging could conceivably be lifesaving.

\section{MATERIALS AND METHODS}

\section{Materials}

Anti-mouse IgG-PE antibody conjugates and antihuman IgG-PE antibody conjugates were purchased from BioLegend (San Diego, CA). Anti-mouse, anti-human, and anti-rabbit HRP-conjugated secondary antibodies were obtained from Jackson ImmunoResearch Laboratories (West Grove, PA). HRP luminescent substrate was acquired from Biorad (Hercules, CA). Horseradish peroxidase (HRP)-streptavidin and EZ-Link SulfoNHS-LC-Biotin were purchased from Thermo Scientific (Madison, WI). Ethanol, xylene, hydrogen peroxide and Tween-20 procured from Sigma-Aldrich (St. Louis, MO). Target Retrieval buffer was obtained from DAKO (Carpinteria, CA). The cancer tissue microarrays examined consisted of a pancreatic cancer microarray from the Translational Genomics Research Institute (Phoenix, AZ), a custom multi-tumor tissue microarray (TMA-00300) from Asterand (Detroit, MI) and a lung cancer microarray from University of Pennsylvania (Philadelphia, PA). Cell culture reagents and all other materials were purchased from VWR (Chicago, IL).

\section{Antibody}

A previously described murine monoclonal antibody raised against human FR- $\alpha$ (mAb343) was used for IHC assessment of FR- $\alpha$ expression [41]. To query FR- $\beta$ expression, a human monoclonal anti-human FR- $\beta$ antibody (m909) was generated against the extracellular domain of human FR- $\beta$ and has been characterized previously in human samples [42]. Antibodies mAb343 and m909 were labeled with EZ-Link Sulfo-NHS-LCBiotin according to manufacturer's instructions. The specificity of biotinylated-m909 for human FR- $\beta$ using this method has been established previously [22].

\section{Cell culture}

MDA-MB-231 and CHO- $\beta$ (CHO cells transfected with a FR- $\beta$ expression vector) were cultured in RPMI 1640 media supplemented with $10 \%$ fetal bovine serum and $1 \%$ penicillin-streptomycin at $37^{\circ} \mathrm{C}$ in a humidified 95\% air $-5 \% \mathrm{CO}_{2}$ atmosphere. Cells were split into a $\sim 1: 8$ ratio when flasks reached confluence. All testing was performed by the 10th passage.

\section{Flow cytometry}

MDA-MB-231 and CHO- $\beta$ cells were dislodged from culture flasks by mechanical scraping in PBS, and cell density was adjusted to $1 \times 10^{6}$ cells $/ \mathrm{mL}$. $0.1 \mathrm{~mL}$ of cells were incubated in the presence or absence of $0.1 \mu \mathrm{g} / \mathrm{mL}$ $\mathrm{mAb} 343$ or $\mathrm{m} 909$ for $30 \mathrm{~min}$ at room temperature. mAb343 treated cells were washed in PBS and then incubated in anti-mouse IgG-PE conjugate for $30 \mathrm{~min}$ at room temperature and m909 treated cells were similarly washed and incubated in anti-human IgG-PE conjugate. Cells were washed in PBS followed by incubation with 7-AAD for $15 \mathrm{~min}$ at room temperature. Cells were then analyzed via flow cytometry (BD Biosciences Accuri C6; San Jose, CA). Live cells were gated and the amount of secondary antibody fluorescence was recorded.

\section{Western blotting}

MDA-MB-231 and CHO- $\beta$ cells were dislodged from culture flasks by mechanical scraping in PBS and cell density was adjusted to $1 \times 10^{6}$ cells $/ \mathrm{mL}$. Cells were lysed in loading buffer and $20 \mu \mathrm{L}$ was added to each well of a $10 \%$ polyacrylamide gel. After electrophoresis, proteins were transferred to nitrocellulose paper and the membrane was blocked with $5 \%$ BSA overnight at $4^{\circ} \mathrm{C}$. After washing with tris-buffered saline $+0.05 \%$ Tween 20 (TBST), membranes were incubated with mAb343 $(1: 10,000), \mathrm{m} 909$ (1:5000), or anti-actin $(1: 20,000)$ in TTBS overnight at $4^{\circ} \mathrm{C}$. The labeled membrane was washed in TBST and then incubated with anti-mouse $(1: 20,000)$, anti-human (1:5000), or anti-rabbit (1:5000) HRP-conjugated secondary antibody for 1 hour at room temperature for $\mathrm{mAb} 343, \mathrm{~m} 909$, and anti-actin treated blots, respectively. Blots were washed with TBST and developed in luminescent HRP substrate prior to imaging using a ProteinSimple FluorChem R camera system (San Jose, CA).

\section{Immunohistochemistry}

All tumor microarrays (TMA) were supplied by the provider fixed in formalin and embedded in paraffin. TMA samples were deparaffinized with xylene (3 changes), 
rehydrated in a series of ethanol dilutions $(100 \%, 95 \%$, then $70 \%$ ) and rinsed in distilled water. TMA slides then were placed in a preheated DAKO Target Retrieval buffer for $40 \mathrm{~min}$, cooled in the same buffer for $20 \mathrm{~min}$ and rinsed for $5 \mathrm{~min}$ in distilled water. After the heat inactivated epitope retrieval step, TMA sections were incubated in $3 \%$ $\mathrm{H}_{2} \mathrm{O}_{2}$ in ethanol for 5 min to inactivate the endogenous peroxides, followed by a protein blocking step for $5 \mathrm{~min}$. Slides were rinsed with Tris-buffered saline containing $0.05 \%$ Tween 20 (TBST) wash buffer and incubated for $30 \mathrm{~min}$ at room temperature with biotinylated-m909 or biotinylated-mAb343 (0.07 mg/mL). TMA sections then were rinsed with TBST wash buffer and incubated with HRP-streptavidin for $10 \mathrm{~min}$ at room temperature. The slides then were washed with TBST and incubated in 3,3'-diaminobenzidine for $5 \mathrm{~min}$ at room temperature, counterstained with Modified Schmidts's Hematoxylin for $5 \mathrm{~min}$ and rinsed in tap water for $3 \mathrm{~min}$. The samples then were dehydrated through graded alcohols, cleared in 3 changes of xylene and mounted with a permanent mounting media. Tumor sections were analyzed by trained pathologists and the staining intensity was scored on a scale of 0 to 3 .

\section{Statistics}

Differences between groups were determined by either a $t$-test (assuming equal variance and 2-tails for all samples) for data sets with only 2 groups or a 1-way ANOVA for data sets containing multiple groups. Correlation analyses were performed using a Spearman correlation analysis. Differences were considered statistically significant if the $p$-value was $<0.05$.

\section{Author contributions}

JS and YH performed experiments. SS, HH, DV, and LM provided cancer specimens, performed IHC and scored tissue sections. KSP analyzed data. KSP and PSL wrote the paper. PSL oversaw the entire project.

\section{CONFLICTS OF INTEREST}

Authors report no conflicts of interest.

\section{GRANT SUPPORT}

Endocyte.

This project was supported by a grant from

\section{REFERENCES}

1. Antony AC. Folate receptors. Annu Rev Nutr. 1996; 16:501-521

2. Weitman SD, Lark RH, Coney LR, Fort DW, Frasca V, Zurawski VR, Kamen BA. Distribution of the folate receptor GP38 in normal and malignant cell lines and tissues. Cancer Res. 1992; 52:3396-3401.

3. Weitman SD, Weinberg AG, Coney LR, Zurawski VR, Jennings DS, Kamen BA. Cellular localization of the folate receptor: potential role in drug toxicity and folate homeostasis. Cancer Res. 1992; 52:6708-6711.

4. O'Shannessy DJ, Somers EB, Albone E, Cheng X, Park YC, Tomkowicz BE, Hamuro Y, Kohl TO, Forsyth TM, Smale $\mathrm{R}, \mathrm{Fu}$ YS, Nicolaides NC. Characterization of the human folate receptor alpha via novel antibody-based probes. Oncotarget. 2011; 2:1227-1243. https://doi.org/10.18632/ oncotarget. 412 .

5. Puig-Kroger A, Sierra-Filardi E, Dominguez-Soto A, Samaniego R, Corcuera MT, Gomez-Aguado F, Ratnam M, Sanchez-Mateos P, Corbi AL. Folate receptor beta is expressed by tumor-associated macrophages and constitutes a marker for M2 anti-inflammatory/regulatory macrophages. Cancer Res. 2009; 69:9395-9403.

6. Kurahara H, Takao S, Kuwahata T, Nagai T, Ding Q, Maeda K, Shinchi H, Mataki Y, Maemura K, Matsuyama T, Natsugoe S. Clinical significance of folate receptor $\beta$-expressing tumor-associated macrophages in pancreatic cancer. Ann Surg Oncol. 2012; 19:2264-2271.

7. Shen F, Ross JF, Wang X, Ratnam M. Identification of a novel folate receptor, a truncated receptor, and receptor type beta in hematopoietic cells: cDNA cloning, expression, immunoreactivity, and tissue specificity. Biochemistry. 1994; 33:1209-1215.

8. Shen F, Wu M, Ross JF, Miller D, Ratnam M. Folate receptor type gamma is primarily a secretory protein due to lack of an efficient signal for glycosylphosphatidylinositol modification: protein characterization and cell type specificity. Biochemistry. 1995; 34:5660-5665.

9. Tian Y, Wu G, Xing JC, Tang J, Zhang Y, Huang ZM, Jia ZC, Zhao R, Tian ZQ, Wang SF, Chen XL, Wang L, Wu $\mathrm{YZ}$, et al. A novel splice variant of the folate receptor 4 predominantly expressed in regulatory $\mathrm{T}$ cells. BMC Immunol. 2012; 13: 30.

10. Low PS, Henne WA, Doorneweerd DD. Discovery and Development of Folic-Acid-Based Receptor Targeting for Imaging and Therapy of Cancer and Inflammatory Diseases. Acc Chem Res. 2008; 41:120-129.

11. O'Shannessy DJ, Somers EB, Wang LC, Wang H, Hsu R. Expression of folate receptors alpha and beta in normal and cancerous gynecologic tissues: correlation of expression of the beta isoform with macrophage markers. J Ovarian Res. 2015; 8:29.

12. Yuan Y, Nymoen DA, Dong HP, Bjørang O, Shih IM, Low PS, Trope' CG, Davidson B. Expression of the folate receptor genes FOLR1 and FOLR3 differentiates ovarian carcinoma from breast carcinoma and malignant mesothelioma in serous effusions. Hum Pathol. 2009; 40:1453-1460.

13. Shia J, Klimstra DS, Nitzkorski JR, Low PS, Gonen M, Landmann R, Weiser MR, Franklin WA, Prendergast 
FG, Murphy L, Tang LH, Temple L, Guillem JG, et al. Immunohistochemical expression of folate receptor alpha in colorectal carcinoma: patterns and biological significance. Hum Pathol. 2008; 39:498-505.

14. Hartmann LC, Keeney GL, Lingle WL, Christianson TJ, Varghese B, Hillman D, Oberg AL, Low PS. Folate receptor overexpression is associated with poor outcome in breast cancer. Int J Cancer. 2007; 121:938-942.

15. Parker N, Turk MJ, Westrick E, Lewis JD, Low PS, Leamon CP. Folate receptor expression in carcinomas and normal tissues determined by a quantitative radioligand binding assay. Anal Biochem. 2005; 338:284-293.

16. O’Shannessy DJ, Yu G, Smale R, Fu YS, Singhal S, Thiel RP, Somers EB, Vachari A. Folate receptor alpha expression in lung cancer: diagnostic and prognostic significance. Oncotarget. 2012; 3:414-425. https://doi.org/10.18632/ oncotarget.489.

17. Saba NF, Wang X, Muller S, Tighiouart M, Cho K, Nie S, Chen Z, Shin DM. Examining expression of folate receptor in squamous cell carcinoma of the head and neck as a target for a novel nanotherapeutic drug. Head Neck. 2009; 31:475-481.

18. Christoph DC, Reyna-Asuncion B, Hassan B, Tran C, Maltzman JD, O'Shannessy DJ, Gauler TC, Wohlsclaeger J, Schuler M, Eberhardt WE, Hirsch FR. Assessment of folate receptor- $\alpha$ and epidermal growth factor receptor expression in pemetrexed-treated non-small-cell lung cancer patients. Clin Lung Cancer. 2014; 15:320-330.

19. Köbel M, Madore J, Ramus SJ, Clarke BA, Pharoah PD, Deen S, Bowtell DD, Odunsi K, Menon U, Morrison C, Lele S, Bshara W, Sucheston L, et al. Evidence for a timedependent association between FOLR1 expression and survival from ovarian carcinoma: implications for clinical testing. An ovarian tumor tissue analysis consortium study. Br J Cancer. 2014; 111:2297-2307.

20. Zhang Z, Wang J, Tacha DE, Li P, Bremer RE, Chen H, Wei B, Xiao X, Da J, Skinner K, Hicks DG, Bu H, Tang P. Folate receptor $\alpha$ associated with triple-negative breast cancer and poor prognosis. Arch Pathol Lab Med. 2014; 138:890-895.

21. Iwakiri S, Sonobe M, Nagai S, Hirata T, Wada H, Miyahara R. Expression status of folate receptor alpha is significantly correlated with prognosis in non-small-cell lung cancers. Ann Surg Oncol. 2008; 15:889-899.

22. Shen J, Putt KS, Visscher DW, Murphy L, Cohen C, Singhal S, Sandusky G, Feng Y, Dimitrov DS, Low PS. Assessment of folate receptor- $\beta$ expression in human neoplastic tissues. Oncotarget. 2015; 6:14700-14709. https://doi.org/10.18632/ oncotarget.3739.

23. Sega EI, Low PS. Tumor detection using folate receptortargeted imaging agents. Cancer Metastasis Rev. 2008; $27: 655-664$.
24. Teng L, Xie J, Teng L, Lee RJ. Clinical translation of folate receptor-targeted therapeutics. Expert Opin Drug Deliv. 2012; 9:901-908.

25. Marchetti C, Palaia I, Giorgini M, De Medici C, Iadarola R, Vertechy L, Domenici L, Di Donato V, Tomao F, Muzii L, Benedetti Panici P. Targeted drug delivery via folate receptors in recurrent ovarian cancer: a review. Onco Targets Ther. 2014; 7:1223-1236.

26. Lorusso PM, Edelman MJ, Bever SL, Forman KM, Pilat M, Quinn MF, Li J, Heath EI, Malburg LM, Klein PJ, Leamon CP, Messmann RA, Sausville EA. Phase I study of folate conjugate EC145 (Vintafolide) in patients with refractory solid tumors. J Clin Oncol. 2012; 30:4011-4016.

27. Fisher RE, Siegel BA, Edell SL, Oyesiku NM, Morgenstern DE, Messmann RA, Amato RJ. Exploratory study of 99mTc-EC20 imaging for identifying patients with folate receptor-positive solid tumors. J Nucl Med. 2008; 49:899-906.

28. Konner JA, Bell-McGuinn KM, Sabbatini P, Hensley ML, Tew WP, Pandit-Taskar N, Vander Els N, Philips MD, Schweizer C, Weil SC, Larson SM, Old LJ. Farletuzumab, a humanized monoclonal antibody against folate receptor alpha, in epithelial ovarian cancer: a phase I study. Clin Cancer Res. 2010; 16:5288-5295.

29. Naumann RW, Coleman RL, Burger RA, Sausville EA, Kutarska E, Ghamande SA, Gabrail NY, Depasquale SE, Nowara E, Gilbert L, Gersh RH, Teneriello MG, Harb WA, et al. PRECEDENT: a randomized phase II trial comparing vintafolide (EC145) and pegylated liposomal doxorubicin (PLD) in combination versus PLD alone in patients with platinum-resistant ovarian cancer. J Clin Oncol. 2013; $31: 4400-4406$.

30. Ledermann JA, Canevari S, Thigpen T. Targeting the folate receptor: diagnostic and therapeutic approaches to personalize cancer treatments. Ann Oncol. 2015; 26:2034-2043.

31. Okusanya OT, DeJesus EM, Jiang JX, Judy RP, Venegas OG, Deshpande CG, Heitjan DF, Nie S, Low PS, Singhal $\mathrm{S}$. Intraoperative molecular imaging can identify lung adenocarcinomas during pulmonary resection. J Thorac Cardiovasc Surg. 2015; 150:28-35.

32. Morris RT, Joyrich RN, Naumann RW, Shah NP, Maurer AH, Strauss HW, Uszler JM, Symanowski JT, Ellis PR, Harb WA. Phase II study of treatment of advanced ovarian cancer with folate-receptor-targeted therapeutic (vintafolide) and companion SPECT-based imaging agent (99m-Tc-etarfolatide). Ann Oncol. 2014; 25:852-858.

33. Armstrong DK, White AJ, Weil SC, Philips M, Coleman RL. Farletuzumab (a monoclonal antibody against folate receptor alpha) in relapsed platinum-sensitive ovarian cancer. Gynecol Oncol. 2013; 129:452-458.

34. Nagai T, Furusho Y, Li H, Hasui K, Matsukita S, Sueyoshi K, Yanagi M, Hatae M, Takao S, Matsuyama T. Production of a high-affinity monoclonal antibody reactive with folate 
receptors alpha and beta. Monoclon Antib Immunodiagn Immunother. 2015; 34:181-190.

35. Tian Q, Stepaniants SB, Mao M, Weng L, Feetham MC, Doyle MJ, Yi EC, Dai H, Thorsson V, Eng J, Goodlett D, Berger JP, Gunter B, et al. Integrated genomic and proteomic analyses of gene expression in Mammalian cells. Mol Cell Proteomics. 2004; 3:960-969.

36. Gry M, Rimini R, Stromberg S, Asplund A, Ponten F, Uhlen M, Nilsson P. Correlations between RNA and protein expression profiles in 23 human cell lines. BMC Genomics. 2009; 10: 365.

37. Cagle PT, Zhai QJ, Murphy L, Low PS. Folate receptor in adenocarcinoma and squamous cell carcinoma of the lung: potential target for folate-linked therapeutic agents. Arch Pathol Lab Med. 2013; 137:241-244.

38. Kirchhoff C, Hale G. Cell-to-cell transfer of glycosylphosphatidylinositol-anchored membrane proteins during sperm maturation. Mol Hum Reprod. 1996; 2:177-184.

39. Guo W, Gao Y, Li N, Shao F, Wang C, Wang P, Yang Z, Li $\mathrm{R}, \mathrm{He}$ J. Exosomes: New players in cancer (Review). Oncol Rep. 2017; 38:665-675.
40. Predina JD, Newton AD, Keating J, Barbosa EM Jr, Okusanya O, Xia L, Dunbar A, Connolly C, Baldassari MP, Mizelle J, Delikatny EJ, Kucharczuk JC, Deshpande $\mathrm{C}$, et al. Intraoperative molecular imaging combined with positron emission tomography improves surgical management of peripheral malignant pulmonary nodules. Ann Surg. 2017; 266:479-488.

41. Franklin WA, Waintrub M, Edwards D, Christensen K, Prendergrast P, Woods J, Bunn PA, Kolhouse JF. New antilung-cancer antibody cluster 12 reacts with human folate receptors present on adenocarcinoma. Int J Cancer Suppl. 1994; 8:89-95.

42. Feng Y, Shen J, Streaker ED, Lockwood M, Zhu Z, Low PS, Dimitrov DS. A folate receptor beta-specific human monoclonal antibody recognizes activated macrophage of rheumatoid patients and mediates antibody-dependent cellmediated cytotoxicity. Arthritis Res Ther. 2011; 13:R59. 